\title{
The Net Generation's Informal and Educational Use of New Technologies
}

\author{
Swapna Kumar \\ University of Florida
}

\begin{abstract}
Many educators have called for the inclusion of new technologies like blogs, wikis, and social bookmarking in higher education to address the learning needs of the Net Generation. Is there really a discrepancy between the personal and educational use of new technologies by undergraduates? What new technologies do they perceive as most beneficial for their learning? A survey piloted with 26 undergraduates in education demonstrated a huge gap in undergraduates' informal and educational use of new technologies, but indicated that students independently apply their technical skills to their coursework. In open-ended responses, students explained how they have benefited from professors' use of online videos, podcasts, wikis and blogs, and how they would like to see them used in the future. The results are discussed in the context of prior research and the need for further empirical evidence on the differences within the group termed the Net Generation is highlighted.
\end{abstract}

Keywords: technology in education; Net Generation; uses of new technologies 


\section{The Net Generation's Informal and Educational Use of New Technologies}

Educators often call for the use of new technologies in higher education based on the Millenial or Net Generation's use of new technologies in their daily lives (Prensky, 2001; Dede, 2005). Claims have been made that the Net Generation, defined as those born between 1977 and 1990, learns differently from prior generations, experiences a disconnect between formal learning environments and personal use of new technologies, and expects to learn with new digital technologies (Buckingham, 2007; Jones \& Fox, 2009). Individualized learning experiences, knowledge sharing, and the use of collaborative and peer feedback have been proposed as successful ways to engage today's youth (Dede, 2005). Some educators, however, have called attention to the lack of empirical evidence for the claim that a whole generation learns differently and have likened such rhetoric to an "academic form of moral panic" (Bennett, Maton, \& Kervin, 2008, p. 782).

What does the existing research reveal about the educational use of new technologies by the Net Generation? Is there a discrepancy in the Net Generation's use of digital technologies for personal and educational purposes? This study investigates undergraduates' use of new technologies, both in their everyday lives and their academic work. First, it explores claims of a digital divide "between in-school and out-of school use" of new technologies (Buckingham, 2007, p. 96). Second, it seeks to determine whether undergraduates independently transfer their familiarity with new technologies in their daily lives to their academic experience. This research attempts to answer these questions by surveying undergraduates' use of new technologies in their daily lives as well as their application of those skills for educational purposes. If the Net Generation does learn differently, it would be important to gain insight into their perspective of the usefulness of Web 2.0 technologies in higher education. The survey, therefore, included open-ended questions to gather data on both the undergraduate perspective of the academic potential of those technologies, and how they would like to see them used. The results of the pilot survey completed by 26 undergraduates are presented in this paper, along with their feedback on item clarity, scale adequacy, and answer choices in the pilot survey.

A survey was developed to answer the following questions:

- How are Web 2.0 technologies used by undergraduate students for non-educational and for educational purposes?

- Which Web 2.0 technologies do undergraduates find most beneficial for learning?

The findings presented in this paper highlight the differences between undergraduates' use of new technologies in their personal lives and for learning, while simultaneously providing insight into the undergraduate perspective about educators' use of such technologies in higher education. The results will help educators and course designers to identify promising approaches for leveraging students' familiarity with new technologies for learning gains, and to use new technologies that motivate and engage undergraduates.

\section{Prior Research on Students' Use of Technology}

The benefits of Web 2.0 (e.g. blogs, wikis, podcasts, and social networking) for teaching and learning have been highlighted by multiple researchers and educators who have provided valuable data in the form of professor perspectives, student feedback, and measured learning outcomes (Elgort, Smith, \& Toland, 2008; Ellison \& Wu, 2008; Farmer, Yue, \& Brooks, 2008; Luce-Kapler, 2007; Oliver \& Goerke, 2007; Woodward, 2007; Xie, Ke, \& Sharma, 2008). 
Because the goal of this study was to develop a survey about undergraduates' personal and educational use of Web 2.0 tools, only survey research about students' use of technology for educational or for personal purposes was reviewed. In the last decade, a number of large-scale studies in the US, UK, and Australia have presented survey data about Millenials' use and access to web-based and mobile technologies (Caruso \& Kvavik, 2005; Jones \& Madden, 2002; Kennedy et al., 2008; Jones \& Fox, 2009; Lenhart \& Madden, 2005, 2007; Roberts, Foehr, \& Rideout, 2005; Sandars \& Schroter, 2007; Smith, 2009). Given the target population for this study, this section excludes research on younger teens and only reviews reports on the use of technology by those born between 1977 and 1990.

\section{Undergraduate Use of New Technologies}

In 2002, a Pew Internet and American Life survey reported that $86 \%$ of college students were online and that $79 \%$ agreed that their educational experience was positively impacted by their Internet use (Jones \& Madden, 2002). This number increased to 84\% in 2006 but communication with instructors $(87 \%)$ or peers $(78 \%)$ continued to be the main focus of students' Internet use for educational purposes, leading the authors to express surprise at the "absence of particularly innovative users of the Internet in academic activities" (Jones et al., 2008, p. 172). The finding that students primarily use technology for word processing and communication in educational environments was reinforced in an Educause Center for Applied Research (ECAR) study by Kvavik, Caruso and Morgan (2004) of 4374 students (95\% aged 25 or below) across 13 institutions in the US. 99.5\% of the respondents used technology for word processing, e-mail, and surfing the Internet, but only $21 \%$ had created web-based content on their own.

Other researchers who studied students' use of Web 2.0 tools have consistently reported more use than creation of online content by undergraduates. In a technology use survey completed by 2120 Australian freshman, Kennedy et al. (2008) reported that 58.6\% regularly read blogs and $43.9 \%$ commented on others' blogs, but only $34.9 \%$ had created their own blogs and $21 \%$ contributed weekly to their own blog. Likewise, the percentage of students aged 18-24 in a UK survey who reported reading others' blogs was substantially higher than those who wrote their own blog (White, 2007). Wikis were unknown to many respondents in White's survey, a finding that coincides with the results of Kennedy et al.'s (2008) survey in which 81.6\% of the freshmen respondents reported that they had not contributed to wikis. White (2007) also stated that at least $60 \%$ of respondents had never heard of social bookmarking (del.icio.us or StumpleUpon). In the 2008 ECAR study of 27,317 undergraduates, only $33 \%$ of participants used audio- or video-creation software and 35.5\% agreed that they like to learn by contributing to wikis, blogs, and websites (Salaway et al., 2008).

\section{Undergraduate Application of New Technologies in Academic Work}

In the foreword to the ECAR 2004 report, Katz (2005) pointed out that students do not seem to automatically transfer their use of technology for social purposes to their learning, that they can "make technology work, but not place these technologies in the service of (academic) work" (p. 8). Kennedy et al. (2008) corroborated by discussing the "technological diversity" of university students - that "we cannot assume that being a member of the 'Net Generation' is synonymous with knowing how to employ technology based tools strategically to optimize learning experiences in university settings" (p. 117). A similar conclusion was reached by Sandars and Schroter (2007) based on responses from 3000 medical students in the UK about 
their familiarity with Web 2.0 technologies. They found high familiarity but low use of new technologies and concluded that high familiarity did not translate to the use of Web 2.0 tools for learning.

The data summarized above offers information about student-initiated use of technologies for learning purposes. However, the use of Web 2.0 technologies by respondents' instructors or the required use of technology by students in their courses was not described except in the ECAR 2008 study, which included specific questions for students about their instructors' use of technology. A few studies did attempt to gauge students' preferences for the use of technologies in instruction. In the ECAR 2004 study, 31\% of students (n=4374) preferred 'extensive' use of technology in the classroom, but only $13 \%$ of students reported that the use of technology in the classroom had improved their learning. Comparatively, in the ECAR 2008 study $(n=27,168)$, although students were very comfortable with basic technology use, only $21.4 \%$ preferred "extensive" use of IT in the classroom and 59.3\% preferred 'moderate' use, with more males than females preferring IT use. The percentage of students who agreed that the use of technology in their courses improved their learning rose to 45.7\% (Salaway et al., 2008). Students' own skills as well as their prior experiences of technology use for learning influenced their responses but students' high levels of technology use did not always result in their preferring the use of technology for educational purposes (Kvavik, 2005). The authors concluded that undergraduates have "a wide range of preferences, uses, skills, and opinions about IT in the academic context. And many of these views and practices change quickly over time” (Salaway et al., 2008, p. 11).

The research reviewed was from different continents, but it indicates that it is imprudent to attribute certain characteristics or uses of technology to a whole generation. Students' use of technology varied within the populations studied, and might also differ depending on socioeconomic status, access to technology at home and at college, and exposure to multiple uses of technology (Caruso \& Kvavik, 2005; White, 2007). The studies reviewed also indicate that the members of the so-called 'Net Generation' are high users of technology in their daily lives, but that they do not often independently transfer those skills to their learning, and do not seem to expect or desire the use of those technologies in their learning environments. It is possible that students lack exposure to the ways in which new technologies could be used for educational purposes because instructors do not use those digital technologies as extensively in their courses. While students' use of Web 2.0 technologies in educational environments was reported in the research, the larger context of instructors' use was not detailed except in the ECAR 2008 study. Students' low expectations of technology use in classrooms could stem from lack of familiarity with ways in which such technologies can enhance teaching and learning. The survey developed in this study enables the comparison of students' use of new technologies for entertainment and social activities, their use of new technologies for academic work, and their experiences with the educational use of such technologies.

\section{Methodology}

The survey used in this pilot study was drafted based on perspectives on Web 2.0 of focus groups consisting of 21 undergraduates, from different disciplines, at a large private university. The focus groups preferred the term "new technologies" to Web 2.0, rejected the frequency of use (e.g. daily or weekly) as a scale, and asked for "do not know what it is" to be included as a response (Kumar, 2009). The resulting survey draft contained questions in three areas:

- Students' informal use of new technologies 
- Students' educational use of new technologies

- Open-ended questions about how students had used those technologies

All students $(n=29)$ in a 2008 undergraduate course in education were invited to voluntarily complete the online survey. Twenty-six students aged 18-24 completed it within the 30 minutes allotted and then provided feedback on the clarity of questions and adequacy of the answer choices, which was integrated into the final survey. Detailed demographic information about the students was not gathered in the pilot iteration of the survey.

\section{Pilot Survey Results}

Participants' informal use of new technologies, educational use of new technologies, and a comparison of the two are presented below, followed by a summary of their comments on the usefulness of new technologies for learning. The quantitative and qualitative data are finally discussed in the context of the research reviewed.

\section{Users, Not Creators of Content Using New Technologies}

Reinforcing the perception of Millenials in prior literature, students in this group demonstrated a very high use of new technologies in their daily lives. One-hundred percent had Facebook accounts and over 75\% used Instant Messaging (IM), blogs, wikis, online forums, YouTube, and Photosharing websites (Figure 1 \& 2). Only 17\% had used del.icio.us informally, consistent with White's (2007) research and prior focus group feedback that most undergraduates do not understand the term "social bookmarking."

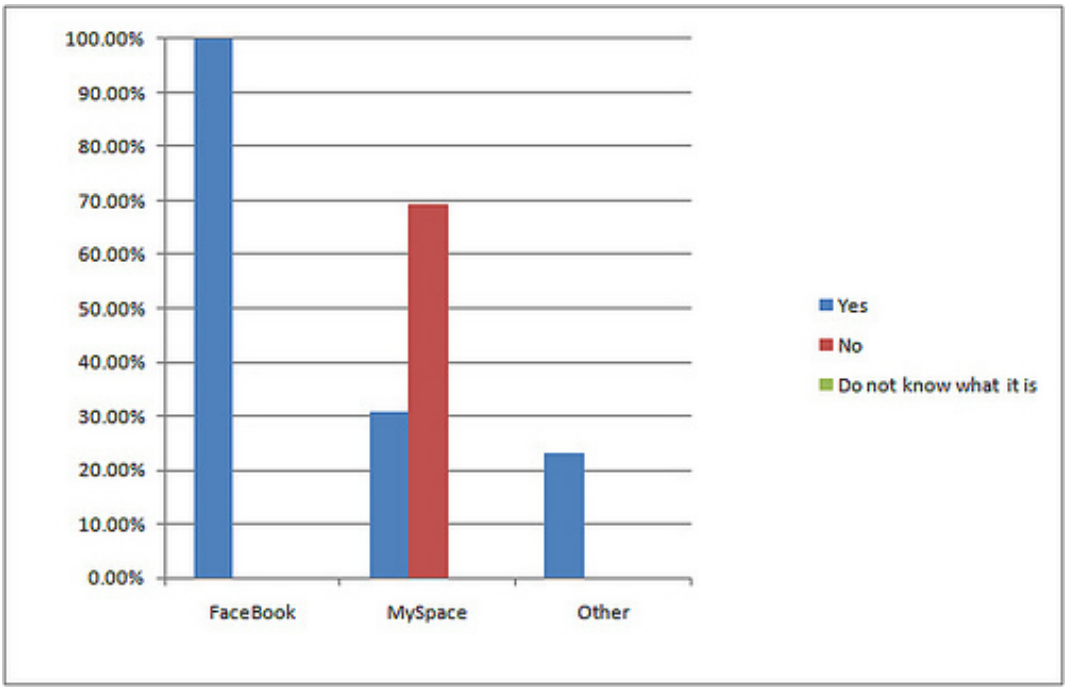

Figure 1. Students' social networking profiles ( $\mathrm{n}=26, \%)$ 


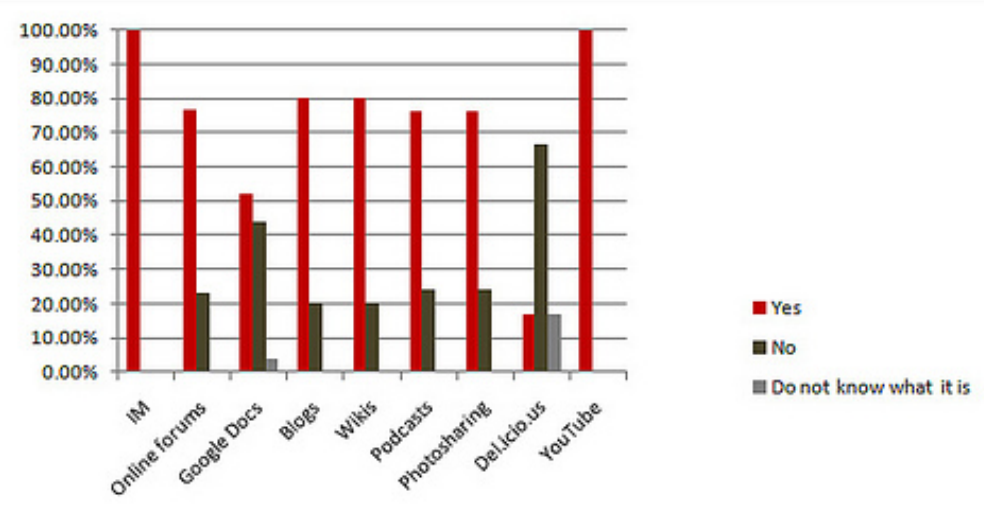

Figure 2. Use of technology for personal purposes ( $\mathrm{n}=26, \%)$

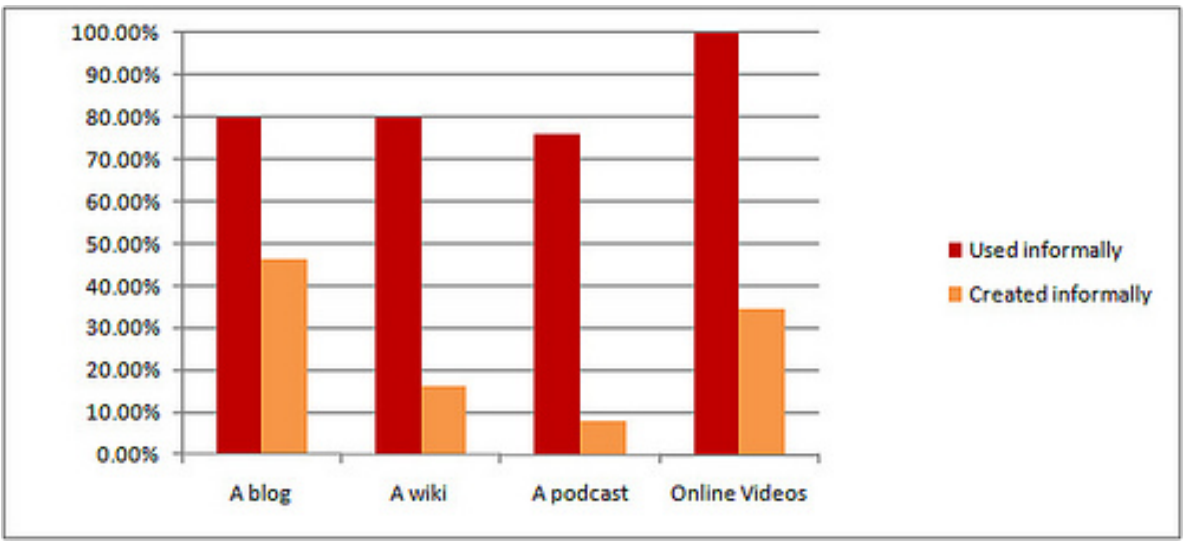

Figure 3. Informal use and creation of online content ( $\mathrm{n}=26, \%)$

Questions about student-created content indicated that undergraduates in this group were consumers, not producers of content using new technologies (Figure 3). Eighty percent of undergraduates used wikis and blogs and 76\% used podcasts informally but their creation of content using the same tools was substantially lower - blogs (47\%), wikis (16\%) and podcasts (8\%).

\section{Low Educational Use of New Technologies}

Over $60 \%$ of respondents had experience with the use of online videos or podcasts in an educational context, but very few reported the use of blogs (24\%), podcasts (23\%) and Google Docs (28\%) in their educational experiences (Figure 4). Students commented that they used Instant Messenger (IM) to discuss assignments and homework with peers, and to prepare for exams. Students questioned the term "educational use" and distinguished between instructor use and students' voluntary use of technology in educational environments, which is discussed later in this paper. 


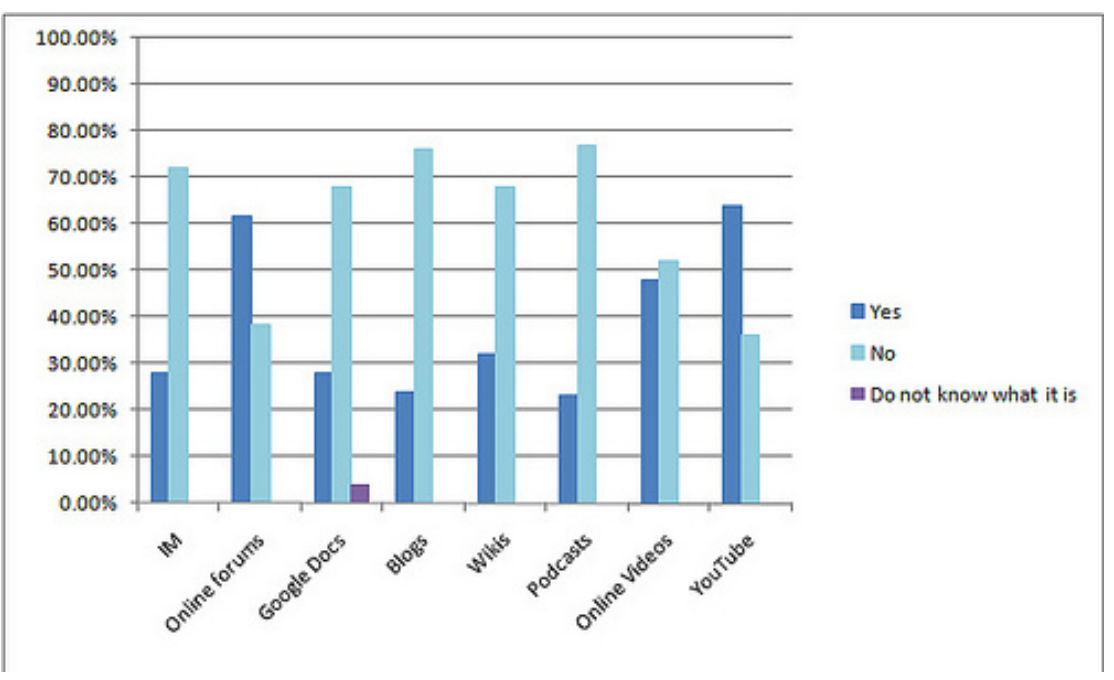

Figure 4. Use of new technologies for educational purposes ( $\mathrm{n}=26, \%)$

Similar to their personal use of new technologies, students' use of online content was higher than their creation of online content for educational purposes (Figure 5). Less than 15\% of undergraduates surveyed had created a blog, wiki, or podcast for their coursework. In openended responses, nine students stated that they would like to create content using wikis, videos, or podcasts, but were not required to do so.

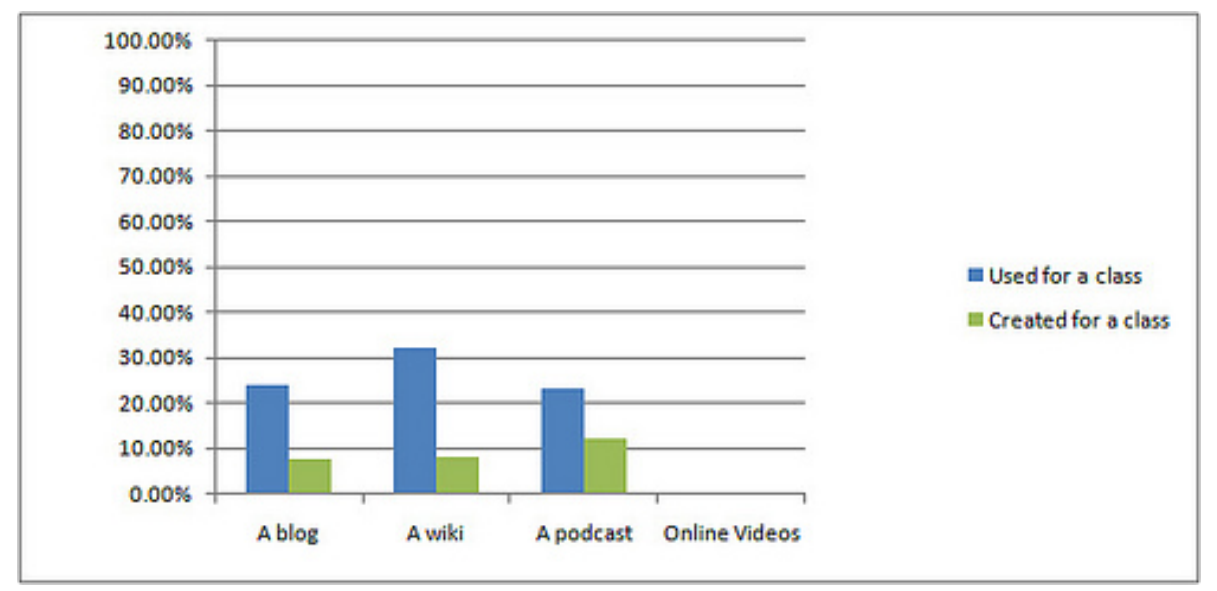

Figure 5. Use and creation of online content for educational purposes $(\mathrm{n}=26, \%)$

\section{The Gap Between Personal and Educational Use}

A comparison of undergraduates' personal and educational use of new technologies emphasized the huge gap between their use of new technologies for teaching and learning and for other purposes (Figure 6). Blogs, wikis, podcasts, and IM were used extensively by the surveyed students for personal purposes but not for educational purposes. Similar to their use of online content, students' creation of online content for educational purposes was even lower than their informal creation of online content (Figure 7). 


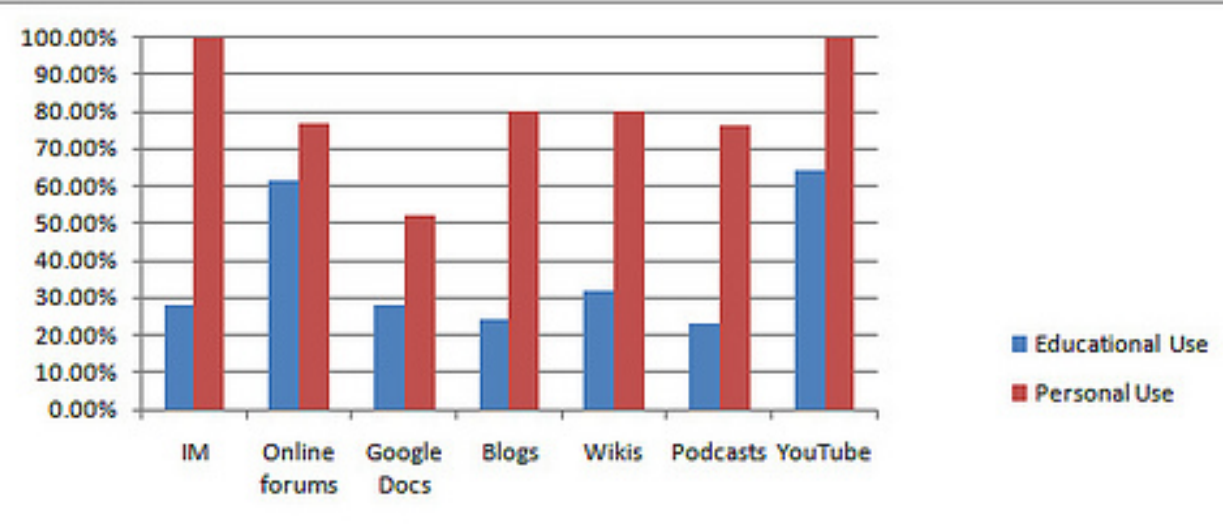

Figure 6. Comparing personal and educational use $(\mathrm{n}=26, \%)$

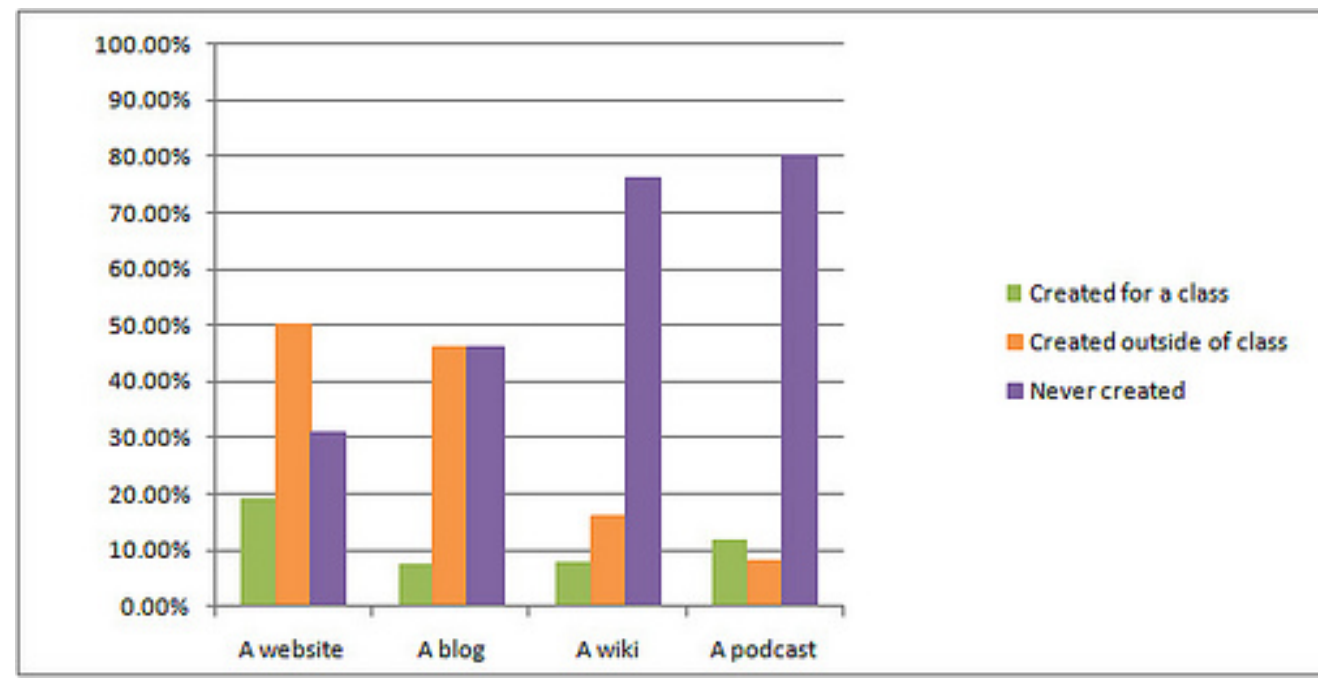

Figure 7. Comparing informal and educational online content creation $(\mathrm{n}=26, \%)$

\section{Technologies Most Useful For Learning}

Additional comments revealed that undergraduates in this group:

- used new technologies for coursework-related information-gathering and communication;

- appreciated the use of online videos and podcasts to supplement course readings;

- enjoyed educational discussions on online forums and blogs; and,

- used Google Docs for collaborative project work and would like to see both wikis and Google Docs used for course activities by professors.

Podcasts and Online videos: Professors' use of videos and podcasts to supplement course content was highly appreciated by students, who added that the length and relevance of a video clip was crucial to its usefulness to course topics. Their professors had used online videos:

- as course resources instead of course readings or supplement to course readings;

- for the explanation of topics; 
- as writing or discussion prompts; and,

- as examples of expert teaching or for integration into lesson plans.

One student provided the following example:

Our professor directed us to view an online video related to a recent discussion that we had had in class. The video was amazingly well put together, and reinforced a great deal that we had covered in class. I found it so helpful, that I forwarded the link to another professor of mine so that he could post it for our other class (in which a similar topic had also come up). Online videos are great tools to reinforce a discussion topic.

Students specified that they would like to see more of podcasts (20\%) and online videos (33\%) in their courses:

They [podcasts and online videos] reinforce discussion topics and place them in an alternative format, allowing students to access/interact with information via different mediums. i.e. it provides alternative interfaces with information. Though they shouldn't replace a lecture, they certainly have value in terms of accessibility (cognitively and physically).

Wikis and Google Docs: Blogs and online forums were popular with undergraduates in this group as an information resource and for "more in-depth" discussions about course topics. Fortyseven percent of students stated that they would like to see blogs used more in their courses. Students also described their use of wikis and Google Docs for collaborative projects and as a personal archive of documents:

I use Google Docs when coordinating labs or joint projects among several team members. Each of us can access the document at anytime and no one has to worry about having multiple copies or coordinating time to meet as a group to work on it.

Twenty-sever percent and $40 \%$ of students suggested that Google Docs and wikis, respectively, should be used for collaborative projects in courses, so that individual contributions could be tracked and students could be graded, or where groups had to turn in one final paper. They claimed that this would ensure that "everyone in the team stays on the same page and maybe even feel more compelled to pull his/her weight.”

\section{Discussion}

The pilot findings of this study indicate that undergraduates in this group are high users of new technologies in their daily lives. Their basic or advanced use of these technologies was not a focus of this study, therefore it is unclear whether they only use a core set of technologies as reported in prior research. Similar to Kennedy et al. (2008)'s study, the 18-24 year olds in this group were consumers, not producers of content using new technologies - few had created blogs (47\%), wikis (16\%) and podcasts (8\%). This has been highlighted as a concern in the literature. While contribution and creation would signify more active engagement with the content, it is also important that students be critical consumers of online content, are able to assess the value of content, and are able to put it to good use in their academic endeavors. There are significant benefits to students creating such artifacts to demonstrate their understanding of a topic, to explore their environment, and to describe their learning experience, but this could be part of an educational experience that leverages their familiarity as consumers of such artifacts. 
Furthermore, being critical and intelligent consumers of online technologies could help them create and contribute to online content in their future professional lives.

Over $60 \%$ of students reported experience with the use of online videos or podcasts, compared to their use of blogs (24\%), podcasts (23\%) and Google Docs (28\%) in an educational context. Given that these data were collected at one institution, it could be argued that this is a reflection of the technologies currently used and expected by instructors at the institutions that the students in this group have attended. For example, it is possible that this group of students have rarely seen presentations that use new media and have not been required to use online technologies in their coursework. If students have had little exposure to the use of new technologies for teaching and learning, they cannot be blamed for not using such technologies for educational purposes. It is for instructors to explore and model the use of new technologies for teaching, and to design curriculum that effectively integrates new technologies for student learning. In their survey feedback, students also explained that they associate 'educational purposes' or 'academic purposes' with classroom use, course use, or professor use of certain technologies, not with their own use of new technologies for studying. Therefore, the findings of this study may well reflect instructor use of Web 2.0 tools and not only students' use of Web 2.0 tools.

The research reviewed reported that 18- to 24-year-olds do not transfer their expertise with technologies to academic contexts (Kennedy et al., 2008; Caruso \& Kvavik, 2005). However, the qualitative data summarized earlier in this paper reveal that students in this group use Instant Messenger when completing assignments, and Google Docs for archiving and group work, even if their professors are unfamiliar with Google Docs. They suggested innovative and relevant ways in which online videos, podcasts, and wikis can enhance their educational experience in contrast to research reported by Caruso and Kvavik (2005) and Kennedy et al. (2008). Students' voluntary descriptions of how these resources have been used in courses that they have attended, as well as their enthusiastic suggestions, signify their interest in the use of new technologies in higher education. Their comments could be attributed to their interest in teaching - students in this group were enrolled in an educational foundations course. One student comment demonstrates that they reflected on the relevance of using new technologies in education:

Most undergraduates are very familiar with all Web 2.0 applications, but rarely are they implemented in courses here, at least the ones that I've taken. Not that that is necessarily a bad thing. Just because technology is available doesn't mean it should be used, only if it can complement or enhance a class.

The findings of this pilot survey, along with the research reviewed, indicate that undergraduates' application of new technologies for academic purposes can be likened to the five stages of technology adoption - Awareness, Adoption, Adaption, Appropriation, and Invention - reported in the Apple Classrooms of Tomorrow research (Dwyer, Ringstaff, \& Sandholz, 1990). Undergraduates are highly aware of new technologies, and adopt them not only for personal use, but also for word processing or communication in education, according to the literature and the results of this survey (Figure 8). Undergraduates' independent transfer or appropriation of new technologies for course collaboration and study groups, as well as their appreciation of the value of new technologies for learning and teaching was not identified in the reviewed research but emerged in this study. Finally, undergraduates' creation of online content for educational purposes was low in both this and prior research. More research is needed on 
undergraduates' creation of online content in academic contexts, and on how their familiarity with technology can be leveraged for innovative and creative applications in their coursework. Given our increasingly virtual and technical world, developing undergraduates' online content creation skills in educational contexts could well be crucial to their future professional lives.

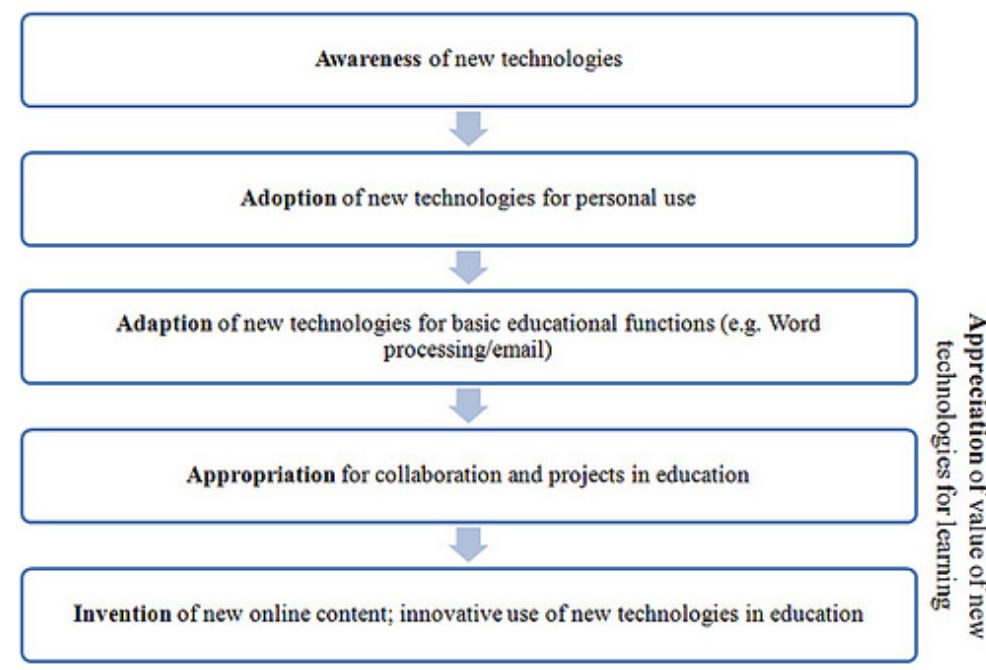

Figure 8. Undergraduates’ integration of technology in education

\section{Implications for Survey Development}

At the beginning of this research, 'educational use' was defined as the use of new technologies in undergraduate courses. No clear distinction was made between professor use and students' use of Web 2.0 applications in a course, on the assumption that if a professor was podcasting or using a wiki in a course, students were also using that tool. The respondents, however, made a distinction between a professor's use of applications and students' use of applications in a course. They provided examples: students could use Google Docs to collaborate and work on a project but the professor need not necessarily be aware of Google Docs. Likewise, a professor would use podcasts and students would listen to and value his podcasts, but did not necessarily understand how a podcast was created. In other cases, both the students and the professor had used the same application, but in different ways. For instance, a student had created a blog for a course assignment and had never created a podcast, but had listened to the professor's podcasts and commented on the professor's blog. These findings made it apparent that the phrase 'educational use' would have to be qualified as: a) professor use or student use and b) the use of each tool separately or a combination thereof in a survey before the usefulness of those applications for learning could be assessed by students. Further, students considered it crucial to include an open-ended question about the ways in which an application was used and why the student perceived it as enhancing his/her learning experience, as this could highlight how instructors or students currently use new technologies.

Students also suggested including social networks other than Facebook (e.g. Twitter), and emerging technologies like Multi-user virtual environments (e.g. SecondLife) in the survey. All suggested changes have since been integrated into the final survey.

\section{Conclusion}

This research was conducted with a small sample of 26 undergraduates of education at an urban private university in 2008, and can therefore not be generalized to all other contexts. 
Nonetheless, the data collected reinforce the importance of gathering concrete evidence to support the many claims made about the Net generation's familiarity and use of new technologies. Empirical evidence of not just students' educational use of technology but simultaneously of their educators' use of technology could provide valuable insight into how educational environments can be improved. Along with the literature reviewed these findings point to the crucial role that technology plays in undergraduates' daily lives and to their lack of exposure to educational uses of those technologies. These findings also contradict prior evidence that the Net generation does not have high expectations of classroom technology use. Students in this research were articulate in suggesting innovative ways in which new technologies can contribute to their academic experiences.

More research is needed on the similarities or differences in the ways that undergraduates use the technology of the time for personal and educational purposes, and on the similarities or differences that exist within the groups or across the groups termed the Net, Millenial, or Neomillenial generation. It is highly problematic to make comparisons about the use of technology by '18-24' year olds across research studies and geographies as this differs according to the time of conducting research - each group studied would have had access and exposure to different technologies at the time, given the rapid evolution of online technologies. Nevertheless, empirical evidence from the undergraduate perspective and dialog with new generations on how the technologies of the time can be used for teaching and learning will be helpful to educators, researchers, and administrators trying to integrate these tools into higher education. 


\section{References}

Bennett, S., Maton, K., \& Kervin, L. (2008). The 'digital natives' debate: A critical review of the evidence. British Journal of Educational Technology, 39(5), 775-786.

Buckingham, D. (2007). Beyond technology: Children's learning in the age of digital culture. Malden, MA: Polity.

Caruso, J.B., \& Kvavik, R. (2005). ECAR study of students and information technology 2005: Convenience, connection, control, and learning. CO: EDUCAUSE Center for Applied Research. Retrieved March 22, 2009 from http://net.educause.edu/ir/library/pdf/ers0506/rs/ERS0506w.pdf

Dede, C. (2005). Planning for Neomillenial learning styles: Implications for investments in technology and faculty. Educause. Retrieved March 22, 2009 from www.educause.edu/educatingthenetgen.

Dwyer, D.C., Ringstaff, C., \& Sandholz, J.H. (1990). Teacher beliefs and practices: Support for change. Cupertino: Apple Computers.

Elgort, I., Smith, A.G., \& Toland, J. (2008). Is wiki an effective platform for group course work? Australasian Journal of Educational Technology, 24(2), 195-210.

Ellison, N., \& Wu, Y. (2008). Blogging in the classroom: A preliminary exploration of student attitudes and impact on comprehension. Journal of Educational Multimedia and Hypermedia, 17(1), 24.

Farmer, B., Yue, A., \& Brooks, C. (2008). Using blogging for higher order learning in large cohort university teaching: A case study. Australasian Journal of Educational Technology, 24(2), 123-136.

Jones, S., \& Madden, M. (2002). The Internet goes to college: How students are living in the future with today's technology. Washington DC: Pew Internet \& American Life Project. Retrieved March 22, 2009 from http://www.pewinternet.org/pdfs/PIP_College_Report.pdf

Jones, S., Johnson-Yale, C., Millermaier, S., \& Seoane Perez, F. (2008). Academic work, the Internet, and U.S. college students. The Internet and Higher Education, 11(3-4), 165-177.

Jones, S., \& Fox, S. (2009). Generations online in 2009. Washington DC: Pew Internet \& American Life Project. Retrieved September 24, 2009 from http://www.pewinternet.org/Reports/2009/Generations-Online-in-2009.aspx

Katz, R. (2005). Foreward: Growing up digital. In J.B. Caruso \& R. Kvavik (Eds.), ECAR study of students and information technology 2005: Convenience, connection, control, and learning. CO: EDUCAUSE Center for Applied Research. Retrieved March 22, 2009 from http://net.educause.edu/ir/library/pdf/ers0506/rs/ERS0506w.pdf

Kennedy, G.E., Judd, T.S., Churchward, A., Gray, K., \& Krause, K.L. (2008). First year students' experiences with technology: Are they really digital natives? Australasian Journal of Educational Technology, (24)1, 108-122.

Kumar, S. (2009). Undergraduate perceptions of the usefulness of Web 2.0 in higher education: Survey Development. In Proceedings of $8{ }^{\text {th }}$ European Conference on E-learning (ECEL), Italy. 
Kvavik, R.B., Caruso, J.B., \& Morgan, G. (2004). ECAR study of students and information technology 2004: Convenience, connection, and control. Boulder, CO: EDUCAUSE Center for Applied Research. Retrieved March 22, 2009 from http://www.educause.edu/ir/library/pdf/ers0405/rs/ers0405w.pdf

Kvavik, R.B. (2005). Convenience, communications, and control: How students use technology. In D. G. Oblinger \& J. L. Oblinger (Eds.), Educating the Net Generation (pp. 7.1-7.20) Educause. Retrieved March 22, 2009 from www.educause.edu/educatingthenetgen.

Lenhart, A., \& Madden, M. (2005). Teen content creators and consumers. Pew Internet, Retrieved January 16, 2008 from http://www.pewinternet.org/pdfs/PIP_Teens_Content_Creation.pdf

Lenhart, A., \& Madden, M. (2007). Teens and social networking. Pew Internet, Retrieved January 16, 2008 from http://www.pewinternet.org/pdfs/PIP_SNS_Data_Memo_Jan_2007.pdf

Luce-Kapler, R. (2007). Radical change and wikis: Teaching new literacies. Journal of Adolescent \& Adult Literacy, 51(3), 214-223.

Oliver, B., \& Goerke, V. (2007). Australian undergraduates' use and ownership of emerging technologies: Implications and opportunities for creating engaging learning experiences for the Net Generation. Australasian Journal of Educational Technology, 23(2), 171-186. http://www.ascilite.org.au/ajet/ajet23/oliver.html

Prensky, M. (2001). Digital natives, digital immigrants. On the Horizon, 9(5), 1-6.

Roberts, D.F., Foehr, U.G., \& Rideout, V. (2005). Generation M: Media in the lives of 8-18 year-olds. Menlo Park, CA: Kaiser Family Foundation.

Salaway, G., Caruso, J.B., Nelson, M.R., \& Ellison, N. (2008). The ECAR study of undergraduate students and information technology, 2008. Boulder, CO: EDUCAUSE Center for Applied Research. Retrieved March 22, 2009 from http://www.educause.edu/ECAR/ResearchPublications/ResearchStudies/1010

Sandars J., \& Schroter S. (2007). Web 2.0 technologies for undergraduate and postgraduate medical education: an online survey. Postgraduate Medical Journal, 83(986), 759-62.

Smith, A. (2009). The Internet as a Diversion. Washington, DC: Pew Internet \& American Life Project. Retrieved September 24, 2009 from http://www.pewinternet.org/Reports/2009/16The-Internet-as-a-Diversion.aspx

White, D. (2007). Results and analysis of the Web 2.0 services survey undertaken by the SPIRE project. UK: JISC funded 'SPIRE' project. Retrieved March 22, 2009 from www.jisc.ac.uk/media/documents/programmes/.../spiresurvey.pdf

Woodward, J. (2007). Podcasts to support workshops in chemistry. Retrieved March 22, 2009 from https://breeze.le.ac.uk/lfconimpalajonny/

Xie, Y., Ke, F., \& Sharma, P. (2008). The effect of peer feedback for blogging on college students' reflective learning processes. The Internet and Higher Education, 11(1),18-25. 